\title{
A SZENTAI-ERDŐ TALAJVÍZSZINT VÁLTOZÁSAI A KASZÓ-LIFE PROJEKT HATÁSÁRA
}

\author{
Eötvös Csaba Béla ${ }^{1}$ és Horváth László ${ }^{2}$ \\ ${ }^{1}$ NAIK ERTI Erdővédelmi Osztály, Mátrafüred \\ ${ }^{2}$ KASZÓ Zrt., Kaszó
}

\begin{abstract}
Kivonat
A talajvíz kutak monitorozása alkalmas módszert ad a talajvízszint-változások hosszú távú elemzéséhez. Segítségével nyomon követhetőek a különböző beavatkozások talajvízháztartásra gyakorolt hatásai. Kutatásaink során a Szentai-erdöben kialakított 18 mintaterületen vizsgáltuk a talajvízszint alakulását. A területet az elmúlt évtizedekben az emberi beavatkozások (vízrendezések, lecsapolások) és az egyenetlen csapadékeloszlás hatására bekövetkező talajvízszint csökkenés jellemezte. A talajvízszint emelését a területet behálózó időszakos vízfolyások medrében a folyásirányra merölegesen elhelyezett mederbordákkal, illetve a már meglévő völgyzárógátas tavak töltéseinek (mütárgyak küszöbszintjeinek) emelésével, továbbá új tavak kialakításával kívántuk elérni. Eredményeink alapján a KASZÓ-LIFE projekt keretében kialakított vízvisszatartó mütárgyak a talajvízszint csökkenésének sebességét mintegy felére lassították, azonban a lehulló csapadék mennyisége nem elegendő ahhoz, hogy a talajvízszint csökkenését meg tudjuk állítani.
\end{abstract}

Kulcsszavak: KASZÓ-LIFE, talajvíz, vízvisszatartás, klímaváltozás

\section{CHANGES OF GROUNDWATER LEVELS IN SZENTA-FOREST AS RESULT OF KASZÓ-LIFE PROJECT}

\begin{abstract}
Monitoring of groundwater wells can give us a reliable method to the long-term analysis of the groundwater levels. With this method we have been able to follow the effects of different interventions to the groundwater recharge. During our experiments the groundwater level changes at 18 sample sites was investigated. The area was characterized by decrease of the groundwater level in the last decades caused by anthropogenic influences such as water management or drainage and by uneven precipitation distribution. We intended to increase the groundwater level by water wales disposed perpendicular to the direction of the flow of the periodic watercourses that encircle the area and by heightening the dams of reservoirs, furthermore by building new reservoirs. In the frame of KASZÓ-LIFE project, according to our results the implemented water retention works did slow down the speed by half of the decrease of the groundwater levels; meanwhile the precipitation have been still not enough to stop the decreasing tendency of groundwater levels.
\end{abstract}

Keywords: KASZÓ-LIFE, groundwater, water retention, climate change 


\section{BEVEZETÉS}

Az elkövetkező ötven évben Magyarország klímájára a szárazodás és a melegedés lesz jellemző (Bartholy 2006, Láng et al 2007, Bartholy et al 2010). Ez a hatás az erdei vizes élőhelyeinken erősen érezteti hatását. A változások hosszú távú fennmaradása esetén ezen erdők fafajösszetétele megváltozik (Führer et al 2011), így a teljes ökológiai müködésre hatással van. Ezt idejekorán felismerve, már az ezredforduló elött elkezdődött pl. a Körös-völgy ökológia vízpótlása, az ottani mentett oldalra került tölgy-köris-szil ligeterdők megóvására. (Puskás 1999). Hasonló munkák folytak 2005-2008 között a Közép-Beregi sík erdős-legelös mozaikos terület lápos élőhelyeinek megóvására (Olajos et al 2009).

Mindemellett az elmúlt több mint száz év vízügyi gyakorlata, mely a folyóink, vízfolyásaink kordában tartását, az árvizek minél gyorsabb lehaladását és a belvizes területek visszaszoritását célozták jelentős mértékben súlyosbítja a kialakult helyzetet.

A víz visszavezetés közvetlen hatásai a mikroklíma változása és a talajvízszint emelkedése, a környezetéhez képest. Jelen munka alapján kijelenthetjük, hogy ez utóbbi hatás még akkor is kimutatható, ha a talajvízszint évröl évre csökken a területen.

\section{ANYAG ÉS MÓDSZER}

Vizsgálatainkat a Dél-Dunántúlon, a Szentai-erdőben végeztük Kaszó környékén (46 19'5.0527" É; $17^{\circ}$ 11' 4.0315" K; 1. ábra). A projek-terület a Nyugat-Belső-Somogy kistájban helyezkedik el, mely tágas lapos mélyedésekkel és É-D-i irányú homokbuckasorokkal tagolt, átlagosan 140-170 méter tengerszint feletti magasságú hordalékkúpsíkság. A kistáj teljes egészében feltöltött süllyedék, mely dombsorait savas kémhatású pleisztocén homok és a völgyekben pannon agyag alkot. A terület éghajlata mérsékelten meleg-mérsékelten nedves, évi középhömérséklet $10,2^{\circ} \mathrm{C}$, vegetációs időszaké $17,0^{\circ} \mathrm{C}$, évi csapadékösszeg $750 \mathrm{~mm}$, vegetációs időszakban $450 \mathrm{~mm}$. A terület északi része a Balaton vízgyüjtőjéhez, déli a Dráváéhoz tartozik, melyekbe a Zala-Somogyi határárok és a Taranyi-Rinya szállitja a vizet. A talajvízszint átlagosan 2-4 méteren található. A talajok jellemzően savanyú kémhatású homokon kialakult barna erdőtalajok (rozsdabarna, kovárványos), homokos váztalajok illetve réti talajok (Becse et al 2010). Elsődleges célunk az enyves éger (Alnus glutinosa (L.) Gaertner) és a magas kőris (Fraxinus excelsior L.) alkotta ligeterdők helyreállitása és megörzése.

A közel 2100 hektáros kaszói projekt-területen 2015 júliusától a KASZÓ-LIFE projekt keretein belül a víz megtartását segítő víztározókat és mederbordákat építettünk ki, melyek a korábbi medermélyítések, kanyarulat levágások és egyéb káros tevékenységek hatásainak visszaforditását szolgálják. A mütárgyak a Küvölgyi 4. tó kivételével 2016-tól üzemelnek, míg a fent említett tó 2017 februárjában lett feltöltve.

Összesen $123 \mathrm{db}$ mederborda lett telepitve 3 időszakos vízfolyás medrében $15 \mathrm{~km}$ hosszan. A mederbordák nagyobb esők után és a hóolvadás időszakában $30 \mathrm{~cm}$-rel emelik meg maguk mögött a vízfolyások vízszintjét. A már meglévő tavak felújitásával és az újak kialakításával a vízfelületet 7,13 ha-ról 16,57 ha-ra növeltük, a víztározó kapacitásuk összesen $136900 \mathrm{~m}^{3}$-re nőtt $68700 \mathrm{~m}^{3}$-röl. A régi tavaknál a mütárgyak felújitásával az üzemvízszint $30 \mathrm{~cm}$-rel, az új tavaknál a barátzsilip és árapasztók beépitésével a vízszintek $110 \mathrm{~cm}$-rel (Bükki-tó), $200 \mathrm{~cm}$-rel (Küvölgyi 3. tó) és $210 \mathrm{~cm}$-rel (Küvölgyi 4. tó) emelkedtek.

A talajvízszint monitorozása lehetővé teszi, hogy a vízvisszatartás indirekt, a növény és állatvilágra gyakorolt hatásai mellett a direkt hatásokat is figyelemmel tudjuk kísérni. A talajvízszint monitorozására 2014 májusában figyelő kutakat létesítettünk 14 mintaterületen és 4 kontrollterületen (1. táblázat és 1. ábra). A kontroll területek vízgyüitő rendszere elkülönül a vizsgálati területekétöl. A kutak gépi fúrással létesültek, 5 méter mélységig alkalmasak a talajvízszint figyelésére. Anyaguk $63 \mathrm{~mm}$ átméröjü, az alsó 2 méteren réselt és 125$130 \mathrm{~g} / \mathrm{m}^{2}$ geotextiliával burkolt, tokos PVC-cső. Felszíni foglalatot és az esetleges talajfelszín fölötti vízállások 
regisztrálására is alkalmas skálát nem kaptak. A kutak a talaj felszíne fölé érnek, a mérések mindig a kútperemtől történtek, a terep fölötti peremmagasságuk a mért értékböl levonásra került, így a terepfelszíntöl számított talajvízmélységet kaptuk. A mérések heti gyakoriságúak voltak, melyet az illetékes kerületvezető erdészek végeztek (2. ábra). A hiányzó adatokat átlagolással pótoltuk. A heti csapadékadatokat a 2014 októberében telepített kaszói meteorológiai mérőállomás szolgáltatta.

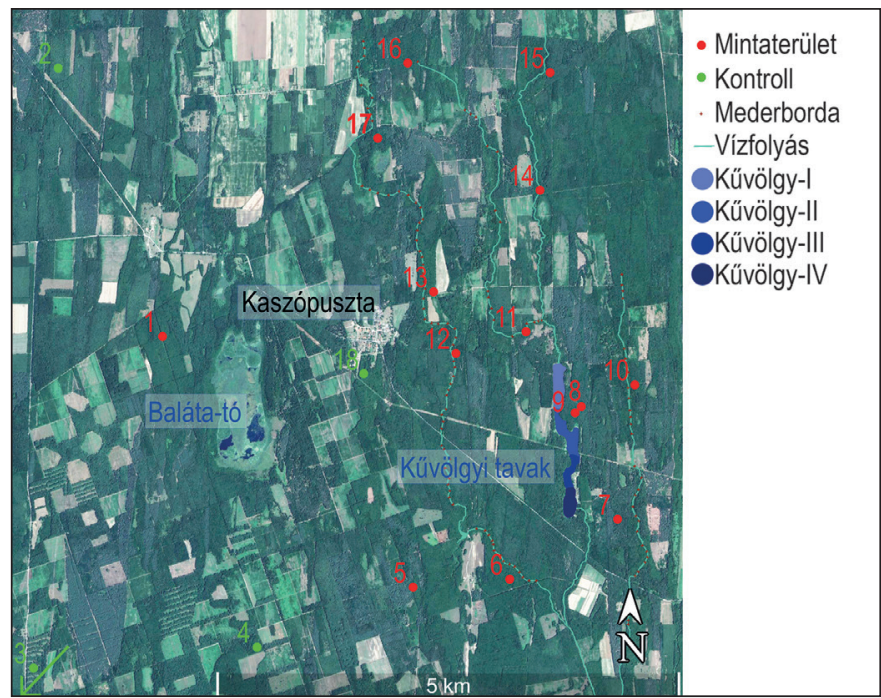

1. ábra: A vizsgálati terület térképe. (A talajvízkutak sorszámozása az 1. táblázat alapján történt.)

Figure 1: The map of the study area. (For the explanation of the ground-water well's numbering see Table 1.)

1. táblázat: A mintaterületek alapadatai

Table 1: The core data of the sample sites

\begin{tabular}{|l|l|l|c|c|}
\hline \multicolumn{1}{|c|}{ Erdörészlet } & \multicolumn{1}{c|}{ Terület típusa } & \multicolumn{1}{c|}{ Uralkodó fafaj } & Kóv) & Sorszám \\
\hline Szenta 46 B & Kontroll & Kocsányos tölgy & 39 & 3. \\
\hline Kaszó 1 S & Kontroll & Kocsányos tölgy & 63 & 2. \\
\hline Szenta 36 C & Kontroll & Mézgás éger & 40 & 4. \\
\hline Kaszó 38 J & Kontroll & Mézgás éger & 53 & 18. \\
\hline Kaszó 27 C & Vizsgálati terület & Kocsányos tölgy & 30 & 12. \\
\hline Somogyszob 30 B & Vizsgálati terület & Kocsányos tölgy & 50 & 8. \\
\hline Kaszó 12 D & Vizsgálati terület & Kocsányos tölgy & 53 & 15. \\
\hline Somogyszob 32 C & Vizsgálati terület & Kocsányos tölgy & 71 & 7. \\
\hline Somogyszob 25 E & Vizsgálati terület & Mézgás éger & 19 & 11. \\
\hline Somogyszob 31 A & Vizsgálati terület & Mézgás éger & 21 & 10. \\
\hline Kaszó 39 C & Vizsgálati terület & Mézgás éger & 27 & 6. \\
\hline Kaszó 9 I & Vizsgálati terület & Mézgás éger & 43 & 16. \\
\hline Kaszó 16 C & Vizsgálati terület & Mézgás éger & 47 & 14. \\
\hline Kaszó 39 L & Vizsgálati terület & Mézgás éger & 49 & 5. \\
\hline Szenta 2 K & Vizsgálati terület & Mézgás éger & 49 & 1. \\
\hline Kaszó 20 F & Vizsgálati terület & Mézgás éger & 50 & 13. \\
\hline Somogyszob 30 J & Vizsgálati terület & Mézgás éger & 50 & 9. \\
\hline Kaszó 18 C & Vizsgálati terület & Mézgás éger & 55 & 17. \\
\hline
\end{tabular}


A heti csapadékösszegek, a talajvízszintek és a kontroll és vizsgálati területek közti talajvízszint-különbségek évenkénti összehasonlítására ANOVA-t használtunk Tukey post hoc teszttel. A számításainkat az R 3.4.4 ( $R$ Core Team, 2018) programmal végeztük. A szignifikancia szintet minden esetben $p<0,001$ értéknél határoztuk meg.

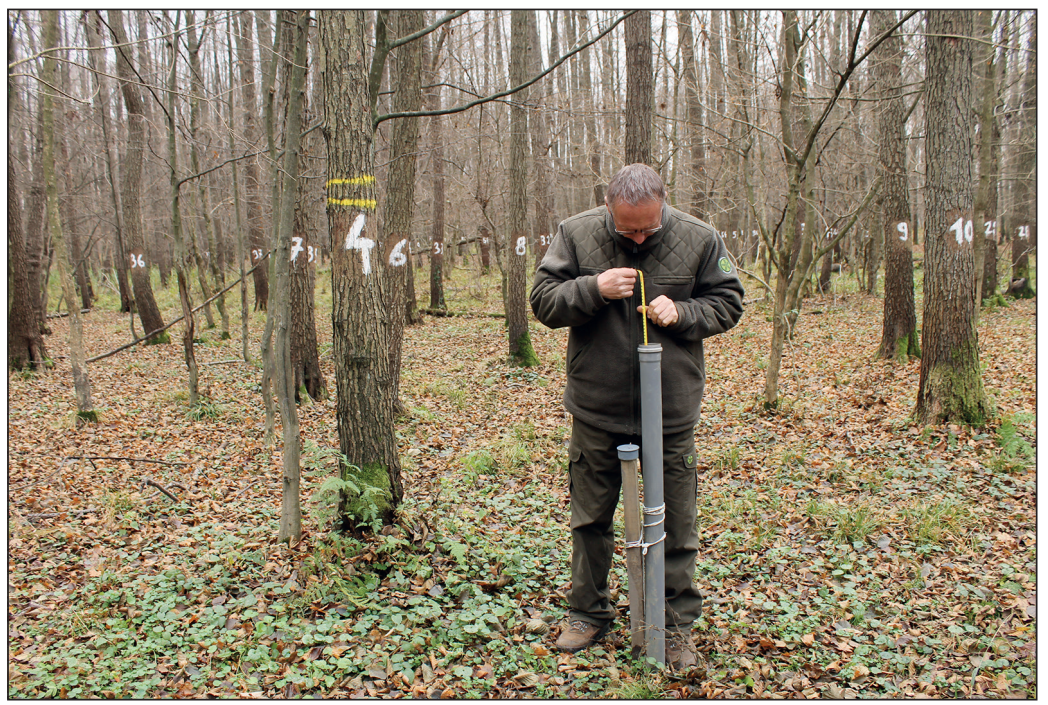

2. ábra: A talajvízszint mérése

Figure 2: Measuring the groundwater level

\section{EREDMÉNYEK ÉS MEGVITATÁSUK}

2. táblázat: Évenkénti átlagos talajvízszintek (cm) a kontroll- és a vizsgálati területeken,

illetve a két területtípus talajvizszint különbségei (cm)

Table 2: Mean groundwater levels $(\mathrm{cm})$ at the control and sample sites, and the difference in the groundwater levels between the control and sample sites $(\mathrm{cm})$

\begin{tabular}{|c|c|c|c|c|c|c|c|c|}
\hline \multicolumn{3}{|c|}{ Kontroll terület } & \multicolumn{3}{c|}{ Vizsgálati terület } & \multicolumn{3}{c|}{ Különbségek } \\
\hline $\mathbf{2 0 1 5}$ & $\mathbf{2 0 1 6}$ & $\mathbf{2 0 1 7}$ & $\mathbf{2 0 1 5}$ & $\mathbf{2 0 1 6}$ & $\mathbf{2 0 1 7}$ & $\mathbf{2 0 1 5}$ & $\mathbf{2 0 1 6}$ & $\mathbf{2 0 1 7}$ \\
\hline$-170,19$ & $-180,58$ & $-263,51$ & $-63,26$ & $-75,22$ & $-107,81$ & 106,93 & 105,37 & 155,70 \\
\hline
\end{tabular}

2015-2017. között nem tapasztaltunk különbséget a lehullt csapadékmennyiségek között $(p=0,961)$ (3. ábra). Az átlagos talajvízszintek a vizsgált időszakban folyamatosan csökkentek a kontroll- és a vizsgálati területeken is (kontroll terület: $p<0,001$; vizsgálati terület: $p<0,001)$ A kontroll és a vizsgálati területek talajvízszintje közti különbség az évek során egyre növekszik ( $p<0,001)$ (2. táblázat és 3-4. ábra). Szignifikáns különbséget 2017. és a korábbi két év talajvízszintjei között sikerült kimutatni (3. táblázat).

Tapasztalati értékek alapján a visszaduzzasztott víztestek legalább 300 méteres környezetben jelentős hatással bírnak a környezetük talajvízszintjére (Puskás 1999). A 2005-ben Beregi síkságon megkezdett vízrendezés, melynek célja a természetközeli állapot létrehozása volt, arról számol be, hogy a projekt keretében regionális szinten megemelkedett a talajvízszint (Olajos et al 2009). Ez összhangban van tapasztalatinkkal, miszerint a vizsgálati területeken lévő összes talajvízkút pozitív mérleget mutat a kontrollhoz viszonyítva, tehát a lokális kezelések a teljes vízgyüjtő területre kifejtették hatásaikat. 
3. táblázat: Tukey post hoc teszt eredményei az ANOVA számítások alapján

Table 3: The results of the Tukey post hoc test according to the ANOVA calculations

\begin{tabular}{|c|c|c|c|c|}
\hline & Különbség & $\begin{array}{c}\text { Konfidencia intervallum } \\
\text { alsó határ }\end{array}$ & $\begin{array}{l}\text { Konfidencia intervallum } \\
\text { felső határ }\end{array}$ & p-érték \\
\hline \multicolumn{5}{|c|}{ Heti csapadékmennyiség } \\
\hline $2015-2016$ & $-0,85$ & $-10,69$ & 8,99 & 0,977 \\
\hline $2015-2017$ & 0,28 & $-9,56$ & 10,12 & 0,998 \\
\hline $2016-2017$ & 1,13 & $-8,75$ & 11,01 & 0,960 \\
\hline \multicolumn{5}{|c|}{ Kontrollterületek talajvízszintje } \\
\hline $2015-2016$ & $-10,39$ & $-29,53$ & 8,74 & 0,406 \\
\hline $2015-2017$ & $-93,33$ & $-112,46$ & $-74,19$ & $<0,001$ \\
\hline $2016-2017$ & $-82,93$ & $-102,16$ & $-63,71$ & $<0,001$ \\
\hline \multicolumn{5}{|c|}{ Vizsgálati területek talajvízszintje } \\
\hline $2015-2016$ & $-11,95$ & $-34,77$ & 10,86 & 0,431 \\
\hline $2015-2017$ & $-44,55$ & $-67,36$ & $-21,74$ & $<0,001$ \\
\hline $2016-2017$ & $-32,59$ & $-55,51$ & $-9,68$ & 0,003 \\
\hline \multicolumn{5}{|c|}{ Talajvízszint különbségek a kontroll- és a vizsgálati területek között } \\
\hline $2015-2016$ & $-1,56$ & $-14,91$ & 11,78 & 0,959 \\
\hline $2015-2017$ & 48,78 & 35,43 & 62,12 & $<0,001$ \\
\hline $2016-2017$ & 50,34 & 36,93 & 63,75 & $<0,001$ \\
\hline
\end{tabular}

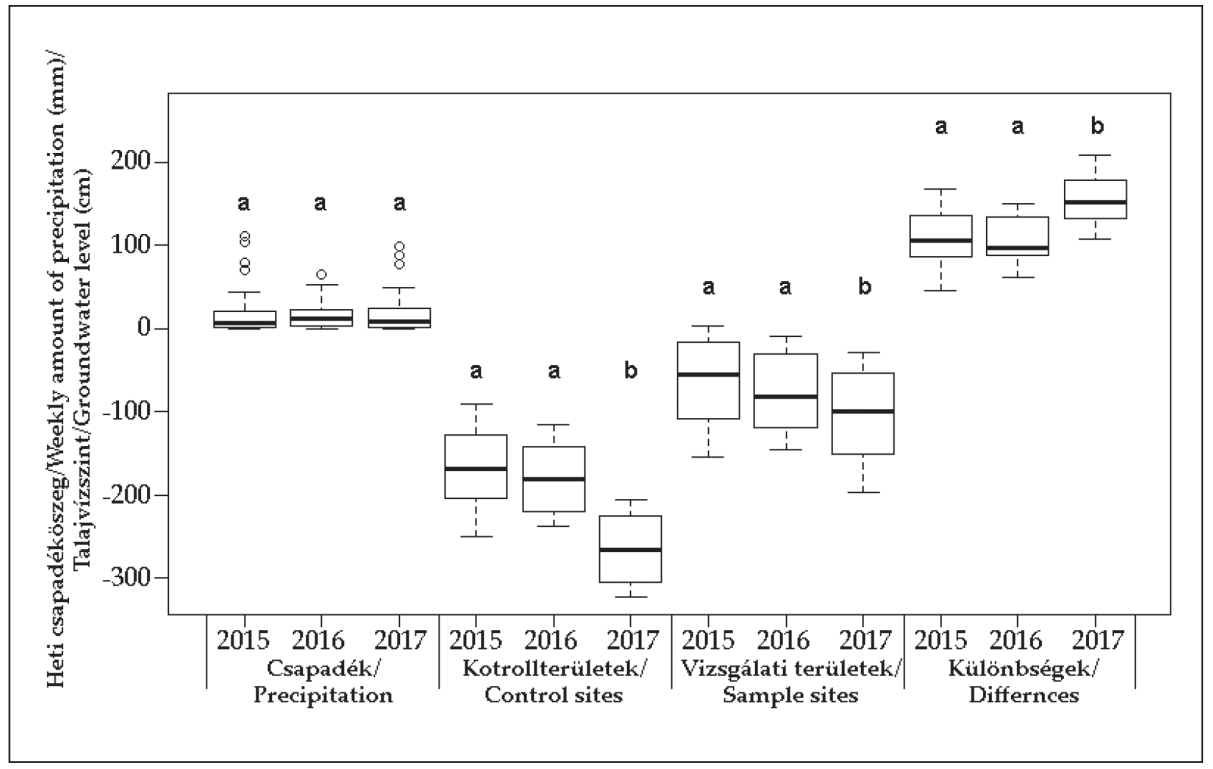

3. ábra: Évenkénti átlagos csapadékmennyiség és talajvízszintek, illetve a kontroll- és vizsgálati területek különbségei A különböző betük szignifikáns különbséget jelölnek

Figure 3: Box plots of precipitation and groundwater levels by year and of the difference of the control and sample sites The different letters mean significant differences 


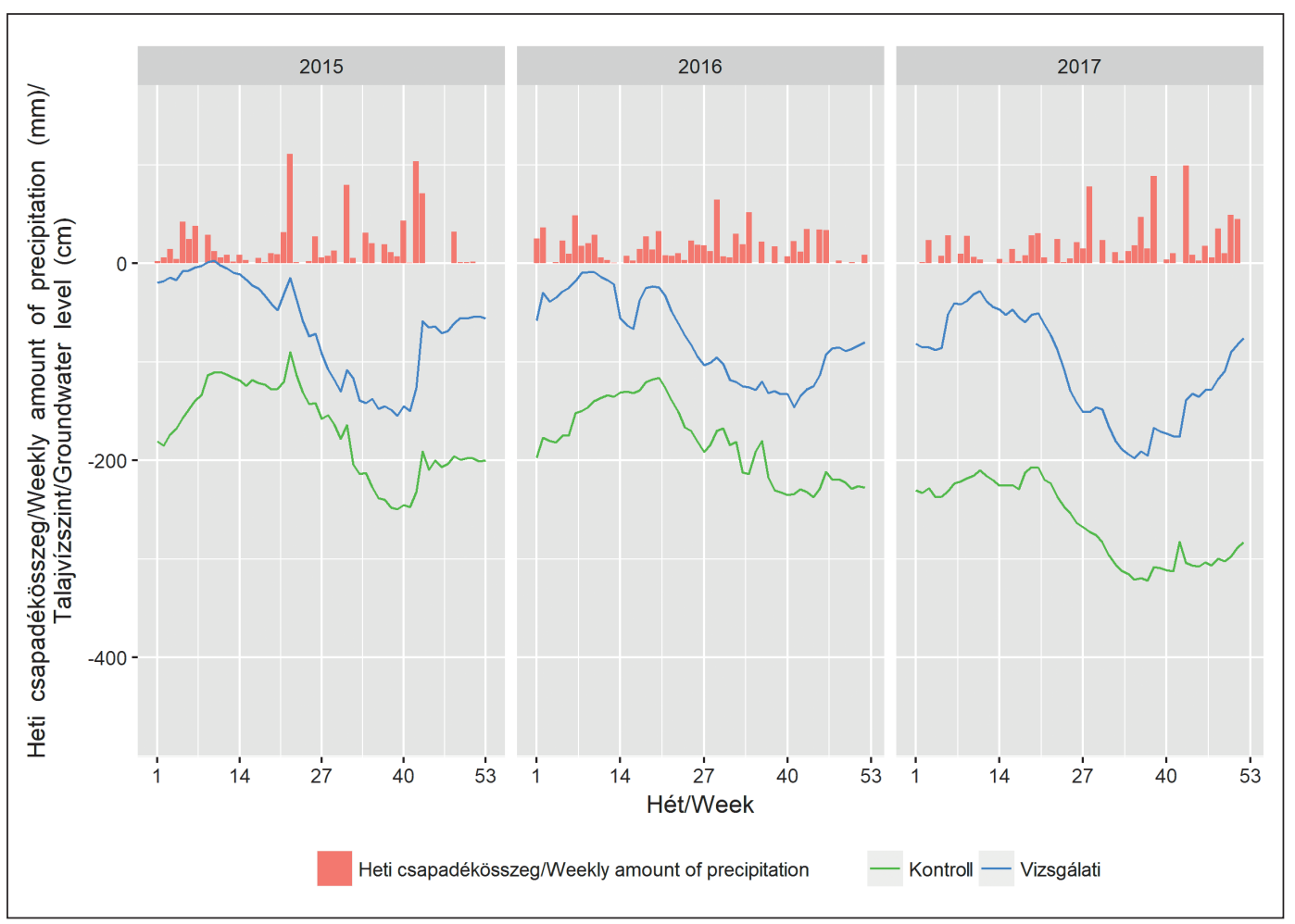

4. ábra: Heti csapadékmennyiségek és átlagos talajvízszintek a kontroll- és a vizsgálati területeken Figure 4: Precipitation and mean groundwater levels by week at the control and sample sites

\section{ÖSSZEFOGLALÁS}

A Szentai-erdőben tapasztalt talajvízcsökkenés azt mutatja, hogy az elmúlt években nem hullott elegendő csapadék a talajvízszint szinten tartásához. A sokéves átlagnál ugyan több csapadék hullott (átlagos különbség=89,2 mm; $n=3$ ), azonban a vegetációs időszakban a csapadék mennyisége elmarad a várt étéktől (átlagos különbség=-9,4 mm; n=3). A csapadékeloszlás változásának következtében, a vegetációs időszakban nem a frissen hullott csapadékból, hanem a raktározódott talajvízkészletből táplálkozik az erdő, így csökkentve a talajvízszintet. A kontroll-területeken 93,32 centiméterrel csökkent a talajvízszint, míg a mintaterületeken csupán 44,55 centiméterrel. Ez a szignifikáns különbség bizonyítja, hogy az általunk létesített víztározók és mederbordák pozitív hatással vannak a talajvízszint alakulására, ezáltal elősegítik az élőhelyek megőrzését. Ezáltal javasoljuk a vizes élőhelyek megőrzésére a jövőben hasonló eszközök használatát.

\section{KÖSZÖNETNYILVÁNÍTÁS}

Kutatásainkat az „Enyves éger (Alnus glutinosa) és magas kőris (Fraxinus excelsior) alkotta ligeterdők (Alno-Padion, Alnion incanae, Salicion albae) helyreállítása és megőrzése Kaszó területén" címü, LIFE12 NAT/ HU/000593 azonosítószámú projektje támogatta az Európai Unió LIFE+ programja keretében 


\section{FELHASZNÁLT IRODALOM}

Bartholy J. 2006: A globális éghajlatváltozás valószínüsíthető klimatikus következményei Magyarországon. Agro-21 füzetek 48: 12-18.

Bartholy J., Pongrácz R. \& Torma C. 2010: A Kárpát-medencében 2021-2050-re várható regionális éghajlatváltozás RegCM-szimulációk alapján. Klíma-21 füzetek 60: 3-12.

Becse A., Mezősi G., Ádám L., et al. 2010: In: Dövényi Z. (ed): Magyarország kistájainak katasztere. Második, átdolgozott kiadás. Budapest, HU: MTA Földrajtudományi Kutatóintézet, 479-483.

Führer E., Marosi Gy. \& Jagodics A. 2011: A klímaváltozás egy lehetséges hatása az erdőgazdálkodásban. Erdészettudományi Közlemények 1(1): 17-28.

Láng I., Csete L. \& Jolánkai M. (eds) 2007: A globális klímaváltozás: hazai hatások és válaszok. A VAHAVA jelentés. Szaktudás Kiadó, Budapest.

Olajos P. et al. 2009: A Közép-Beregi sík komplex élőhely-rehabilitációja. LIFE program eredményei (2005-2008). In: Körmöczi L. (ed): 8. Magyar Ökológus Konferencia. Szeged, HU, 167.

Puskás L. 1999: Ökológiai vízpótlás a Körös-völgy erdeiben. In: Gácsi Z. (ed): ERDŐ-víZ - Szemelvények az erdészeti és gyakorlati munkákból. Kecskemét, HU: Magyar Hivatalos Közlönykiadó Lajosmizsei Nyomdája, 50-63.

\section{On-line forrás}

R Core Team 2018: R: A Language \& Environment for Statistical Computing. https://www.R-project.org/.

Érkezett: 2018. augusztus 2.

Közlésre elfogadva: 2018. szeptember 21. 